\title{
PREDIKSI JUMLAH MAHASISWA REGISTRASI PER SEMESTER MENGGUNAKAN LINIER REGRESI PADA UNIVERSITAS ICHSAN GORONTALO
}

\author{
Amiruddin', Rezqiwati Ishak ${ }^{2}$ \\ 1amier.76@gmail.com, 2rezqi.uig@gmail.com \\ ${ }^{12}$ Universitas Ichsan Gorontalo
}

\begin{abstract}
Abstrak
Peningkatan mutu pendidikan, mutu pelayanan dan peningkatan nilai akreditasi adalah harapan semua perguruan tinggi khususnya di Universitas Ichsan Gorontalo. Salah satu faktor untuk mencapai hal tersebut adalah meningkatnya jumlah mahasiswa yang melakukan registrasi pembayaran setiap semester. Berdasarkan laporan di PDPT Dikti tahun pelaporan 2017/2018 memiliki jumlah mahasiswa \pm 9.000 orang, dari analisa 4 tahun terakhir jumlah mahasiswa yang tidak registrasi cenderung meningkat dan mahasiswa registrasi cenderung menurun, jika hal ini tidak diperhatikan, maka akan berdampak pada pencapaian harapan tersebut di atas. Untuk mengatasi masalah tersebut perlu dilakukan teknik prediksi menggunakan metode Linier Regresi dan MAPE. Tujuan dari penelitian ini adalah membangun aplikasi untuk memprediksi jumlah mahasiswa registrasi. Berdasarkan hasil penelitian dari 2 prodi yang dipilih yakni prodi Teknik Informatika didapatkan hasil tingkat error $4.24 \%$ atau tingkat akurasi $95.76 \%$, dan untuk prodi IImu Hukum didapatkan tingkat error $7.69 \%$ atau tingkat akurasi $92.31 \%$, dengan demikian aplikasi yang sudah dibangun layak untuk digunakan.
\end{abstract}

Kata Kunci : Registrasi Mahasiswa, Linier Regresi, MAPE

\begin{abstract}
Improving the quality of education, service quality and accreditation value increase is the hope of all universities, especially at Ichsan University of Gorontalo. One of the factors to achieve this is the increasing number of students who make the payment registration every semester. Based on the report in PDPT Dikti reporting year 2017/2018 has the number of students $\pm 9,000$ people, from the analysis of the last 4 years the number of unregistered students tends to increase and students registerasi tends to decrease, if this is not considered, it will have an impact on the achievement of the above expectations. To overcome these problems, need to be done prediction technique using Linear Regression and MAPE method. The purpose of this research is to build an application to predict the number of registration students. Based on the results of research from 2 selected study program of Informatics Engineering, the result of error rate is $4.24 \%$ or the accuracy level is $95.76 \%$, and for the Law Study program, the error rate is $7.69 \%$ or the accuracy level is $92.31 \%$, thus the application already built is feasible to use.
\end{abstract}

Keywords: Student Registration, Linear Regression, MAPE

\section{Pendahuluan}

Saat ini persaingan antar perguruan tinggi khususnya perguruan tinggi swasta berada dalam lingkup yang sangat kompetitif. Setiap perguruan tinggi berusaha untuk terus memperbaiki manajemennya dalam meningkatkan mutu pendidikan, mutu pelayanan dan peningkatan nilai akreditasi. Hal ini juga yang terus dilakukan oleh Universitas Ichsan Gorontalo supaya tetap bisa eksis di dunia pendidikan tinggi.

Universitas Ichsan Gorontalo adalah salah satu perguruan tinggi swasta terbesar di Provinsi Gorontalo, sesuai dengan laporan di Pangkalan Data Pendidikan Tinggi (PDPT) untuk tahun pelaporan 2017/2018 memiliki jumlah mahasiswa \pm 9.000 orang (forlap.ristekdikti.go.id diakses pada April 2018). Universitas Ichsan Gorontalo berdiri sejak tahun 2001 dengan membina 6 Fakultas yang terdiri dari 11 Program Studi. Sejak berdiri hingga saat ini terus mengalami peningkatan disemua aspek secara signifikan khususnya dari segi jumlah mahasiswa. Memiliki jumlah mahasiswa yang relatif cukup besar bukan berarti tidak ada lagi permasalahan, jika dicermati dan dianalisis ternyata jumlah mahasiswa yang \pm 9.000 orang tidak semuanya melakukan registrasi setiap awal semester.

Berikut ini data jumlah mahasiswa yang melakukan registrasi dan tidak registrasi setiap awal semester untuk empat tahun terakhir. 


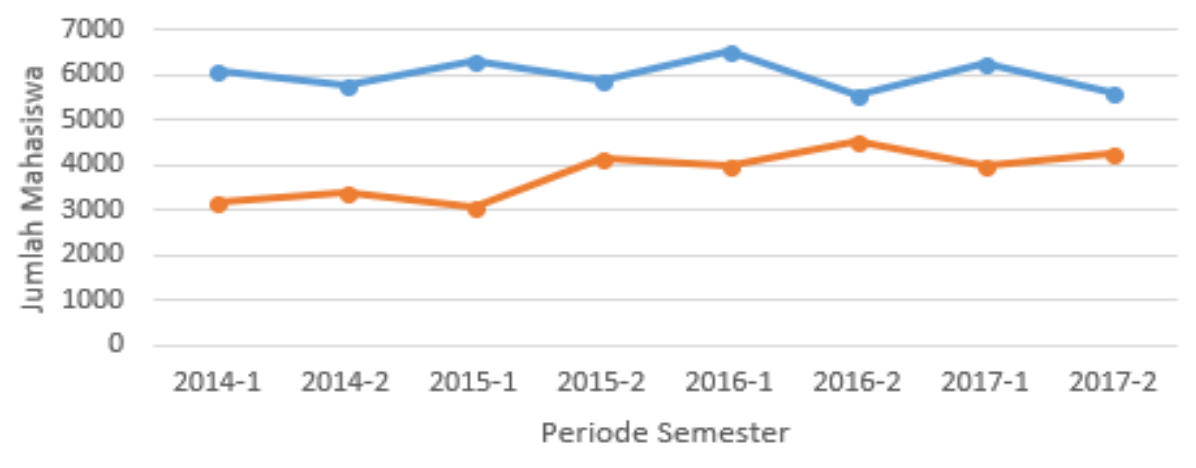

—Registrasi —Tidak Registrasi

Gambar 1. Grafik Jumlah Mahasiswa Registrasi dan Tidak Registrasi 4 Tahun Terakhir Sumber : BAUK Unisan Gorontalo, 2018

Berdasarkan grafik di atas terlihat bahwa jumlah mahasiswa yang melakukan registrasi dan tidak registrasi setiap semesternya mengalami fluktuatif dimana jumlah mahasiswa yang registrasi cenderung menurun dan mahasiswa tidak registrasi cenderung meningkat. Jika hal ini terus dibiarkan tidak dilakukan analisis maka akan berdampak pada biaya operasional kampus. Banyaknya mahasiswa yang registrasi setiap awal semester berarti penerimaan anggaran biaya semakin besar pula, tentunya semua rencana yang sudah ditetapkan dapat dilaksanakan dengan baik, namun sebaliknya akan berdampak menurunya penerimaan biaya operasional dan dampak lainnya adalah meningkatnya mahasiswa non-aktif. Mahasiswa non-aktif adalah mahasiswa yang tidak melakukan registrasi pada awal semester atau tidak mengikuti perkuliahan sekurang-kurangnya satu semester[1].

Melihat permasalahan di atas, maka perlu dilakukan upaya-upaya agar jumlah mahasiswa yang melakukan registrasi setiap semester terus meningkat dan sebaliknya mahasiswa tidak registrasi bisa dikurangi seminimal mungkin. Proses registrasi yang diterapkan oleh pihak manajemen Universitas Ichsan Gorontalo yaitu mahasiswa melakukan pembayaran/registrasi untuk semester berikutnya dilakukan diakhir semester berjalan (Hasil Wawancara pihak BAUK Unisan, 2018).

Proses pembayaran yang diterapkan oleh pihak manajemen sampai saat ini belum bisa diikuti oleh semua mahasiswa, kenyataannya masih banyak mahasiswa tidak bisa melakukan registrasi tepat pada waktunya, sehingga jumlah anggaran yang akan diterima setiap awal semester agak sulit diprediksi berapa jumlahnya. Salah memprediksi jumlah penerimaan yang akan diterima akan berdampak pada rencana pelaksanaan program-program kerja yang sudah direncanakan. Untuk mengatasi masalah tersebut di atas salah satu solusinya adalah melakukan prediksi jumlah mahasiswa yang akan melakukan registrasi untuk semester berikutnya. Berdasarkan data-data yang sudah dikumpulkan dan berdasarkan penelitian-penelitian sebelumnya, maka masalah di atas dapat dilakukan dengan teknik prediksi.

Prediksi merupakan kegiatan untuk memperkirakan apa yang akan terjadi pada masa yang akan datang. Proses perkiraan pengukuran berdasarkan data yang relevan dengan masa lalu dan di analisis secara ilmiah menggunakan metode statistika yang bertujuan untuk memperbaiki peristiwa yang akan terjadi pada masa yang akan datang. Dengan kata lain prediksi bertujuan untuk mendapatkan perkiraan yang bisa meminimumkan kesalahan prediksi (forecast error) yang biasanya diukur dengan Standard Error Estimate (SEE), Mean Absolute Percent Error (MAPE) dan sebagainya[2].

Aplikasi prediksi jumlah mahasiswa registrasi setiap semester yang akan dibuat menggunakan metode Linier Regresi, karena metode ini merupakan salah satu metode yang dapat digunakan untuk melakukan prediksi dan metode ini telah dibuktikan oleh beberapa penelitian sebelumnya, diantaranya penelitian yang dilakukan oleh Mhd. Yogi Pratama[3], dimana hasil penelitiannya didapatkan hasil yaitu pengujian validasi aplikasi menunjukkan bahwa perhitungan yang dilakukan oleh aplikasi sudah sesuai dengan hasil perhitungan secara manual. Aplikasi yang dibuat dapat digunakan untuk memprediksi jumlah pengunjung yang akan datang. Penelitian yang dilakukan oleh Muhammad Ridwan dan Hibertus Himawan[4], berdasarkan hasil penelitiannya metode yang diusulkan yaitu Linier Regresi berhasil diimplementasikan untuk menyelesaikan kasus peramalan jumlah wisatawan. Metode Linier Regresi cukup akurat untuk dimplementasikan pada kasus peramalan karena mempunyai nilai error sebesar $22 \%$ atau mempunyai akurasi $78 \%$. Dari hal tersebut membuktikan bahwa metode Linier Regresi dapat diterapkan pada kasus ini untuk dapat 
memberikan solusi terbaik dalam memprediksi jumlah mahasiswa registrasi untuk semester berikutnya per Program Studi.

\section{Metode}

\subsection{Data Mining}

Data Mining didefinisikan sebagai proses untuk mendapatkan informasi yang berguna dari gudang basis data yang besar. Data mining juga dapat diartikan sebagai pengekstrakan informasi baru yang diambil dari bongkahan data besar yang membantu dalam pengambilan keputusan. Istilah data mining kadang disebut juga Knowledge Discovery (Tan dalam Eko Prasetyo) [5]. Menurut Daryl Pregibon menyatakan bahwa "Data mining adalah campuran statistik, kecerdasan buatan, dan riset basis data"[6].

Data mining merupakan inti dari proses Knowledge Discovery in Database (KDD). KDD adalah proses terorganisir untuk mengidentifikasi pola yang valid, baru, berguna, dan dapat dimengerti dari sebuah dataset yang besar dan kompleks[7].

\subsection{Proses Tahapan Data Mining}

Istilah data mining dan Knowledge Discovery in Databases (KDD) sering digunakan secara bergantian untuk menjelaskan proses penggalian informasi dalam database. Secara garis besar proses KDD dapat dijelaskan sebagai berikut[7]:

1. Pembentukan pemahaman domain aplikasi

2. Memilih dan membuat data set dimana proses penemuan knowledge akan dilakukan.

3. Preprocessing dan cleaning

4. Transformasi data

5. Memilih tugas data mining yang cocok

6. Memilih algoritma data mining

7. Penggunaan algoritma data mining

8. Evaluasi

9. Penggunaan pengetahuan yang didapat.

\subsection{Forecasting}

Peramalan (forecasting) adalah seni dan ilmu untuk memperkirakan kejadian di masa depan. Hal ini dapat dilakukan dengan melibatkan pengambilan data historis dan memproyeksikannya ke masa mendatang dengan suatu bentuk model matematis. Selain itu, bisa juga merupakan prediksi intuisi yang bersifat subjektif. Atau dapat juga dilakukan dengan menggunakan kombinasi model matematis yang disesuaikan dengan pertimbangan yang baik dari seorang manajer[8].

Forecasting berperan sangat penting dalam bisnis. Kemampuan untuk memprediksi secara akurat kejadian di masa depan menjadi dasar dalam pengambilan keputusan. Kemampuan forecasting banyak dipakai di bidang marketing, produksi, pengendalian inventori, dan banyak aktivitas bisnis lainnya.

Penentuan periode waktu peramalan tergantung pada situasi dan kondisi aktual dan tujuan peramalan. Periode waktu yang biasa digunakan adalah harian, mingguan, bulanan, triwulan, semesteran, dan tahunan. Semakin jauh periode mendatang yang akan diramalkan maka hasil ramalan akan semakin kurang akurat. adalah[8]:

Ada berapa macam tipe peramalan yang digunakan. Adapun tipe-tipe dalam peramalan

1. Times Series Model

Metode time series adalah metode peramalan secara kuantitatif dengan menggunakan waktu sebagai dasar peramalan.

2. Causal Model

Metode peramalan yang menggunakan hubungan sebab-akibat sebagai asumsi, yaitu bahwa apa yang terjadi di masa lalu akan terulang pada saat ini.

3. Judgemental Model

Bila time series dan causal model bertumpu pada kuantitatif, pada judgemental mencakup untuk memasukkan faktor-faktor kuantitatif/subjektif ke dalam metode peramalan. Secara khusus berguna bilamana faktor-faktor subjektif yang diharapkan menjadi sangat penting bilamana data kuantitatif yang akurat sudah diperoleh.

\subsection{Metode Linear Regresi}

Analisis Regresi adalah teknik statistik untuk pemodelan dan investigasi hubungan dua atau lebih variabel, yang sering dipakai dan paling sederhana adalah Linier Regresi sederhana. Dalam 
analisis Regresi ada satu atau lebih variabel independent yang bisa diwakili dengan notasi $x$ dan satu variabel respon yang bisa diwakili dengan notasi y. Sesuai namanya, hubungan antara dua variabel ini bersifat linier[9].

Linier Regresi termasuk dalam time series model yang menggunakan metode kuantitatif dengan menggunakan waktu sebagai dasar peramalan. Linier Regresi mempunyai persamaan dasar sebagai berikut :

dimana :

$$
Y=a+b x
$$

$\mathrm{Y}$ : nilai ramalan periode ke-t

a : intersept

$\mathrm{b}:$ slope dari garis kecenderungan, merupakan tingkat perubahan

$\mathrm{x}$ : indeks waktu $(\mathrm{t}=1,2,3, \ldots, \mathrm{n})$; $\mathrm{n}$ adalah banyaknya periode waktu

Komponen pada Linier Regresi ada tiga yaitu a sebagai intersept, b sebagai slope dan $\mathrm{x}$ sebagai indeks waktu. Perasamaan untuk mendapatkan nilai a dan b adalah :

$$
\begin{aligned}
& a=\frac{\left(\sum y\right)\left(\sum x^{2}\right)-\left(\sum x\right) \sum x y}{n \sum x^{2}-\left(\sum x\right)^{2}} \\
& b=\frac{n\left(\sum x y\right)-\left(\sum x\right)\left(\sum y\right)}{n\left(\sum x^{2}\right)-\left(\sum x\right)^{2}}
\end{aligned}
$$

Langkah-langkah metode yang diusulkan berdasarkan Linier Regresi sebagai berikut :

1. Pembuatan dataset yang terdiri dari data training dan data testing

2. Pembentukan model Linier Regresi (model dibuat berdasarkan data training).

Langkah pembentukan model sebagai berikut:

a. Langkah 1: Hitung $\mathrm{X}^{2}, \mathrm{Y}^{2}, \mathrm{XY}$ dan total dari masing-masingnya

b. Langkah 2: Hitung a dengan menggunakan persamaan (2) dan b menggunakan persamaan (3).

c. Langkah 3: Buatkan model persamaan Linier Regresi sederhana.

d. Langkah 4: Lakukan prediksi atau peramalan terhadap variabel faktor penyebab atau variabel akibat

3. Pengujian performa berdasarkan model prediksi yang telah dibuat dengan input data testing. Mean Absolute Percentage Error (MAPE) merupakan metode yang digunakan untuk menilai tingkat keakuratan[10].

dimana :

$$
M A P E=\frac{\sum \frac{\left|y-y^{\prime}\right|}{y} x 100 \%}{n}
$$

$$
\begin{array}{ll}
\text { y' } & \text { : hasil prediksi } \\
\text { y } & : \text { Data aktual } \\
n & : \text { Jumlah data }
\end{array}
$$

\section{Hasil dan Pembahasan}

Penelitian ini menghasilkan sebuah sistem dekstop yang dibangun menggunakan bahasa pemrograman Visual Basic Net dan database MySql. Berikut beberapa tampilan form dari aplikasi prediksi yang sudah dibuat :

a. Tampilan Form Entry Dataset

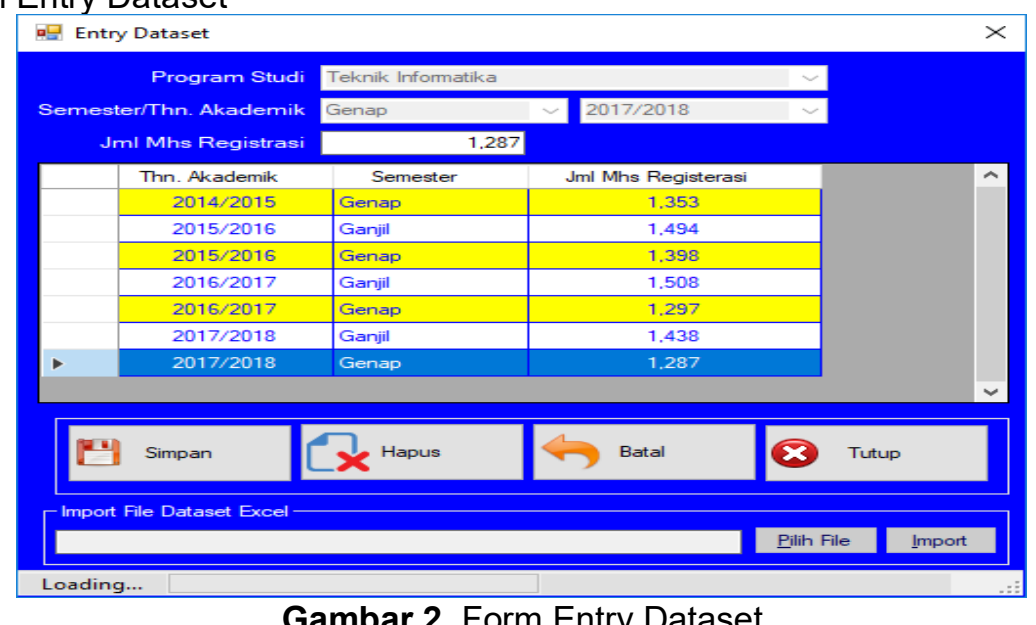

Gambar 2. Form Entry Dataset 
Form ini digunakan untuk melakukan entry dataset yang akan digunakan dalam perhitungan Linier Regresi. Entry dataset dapat juga dilakukan dengan cara import data dari file excel yang sudah disiapkan sebelumnya.

b. Tampilan Form Proses Perhitungan Metode Linier Regresi

Setelah semua dataset di input ke dalam sistem, maka dapat dilakukan proses perhitungan metode Linier Regresi dengan menggunakan form berikut :

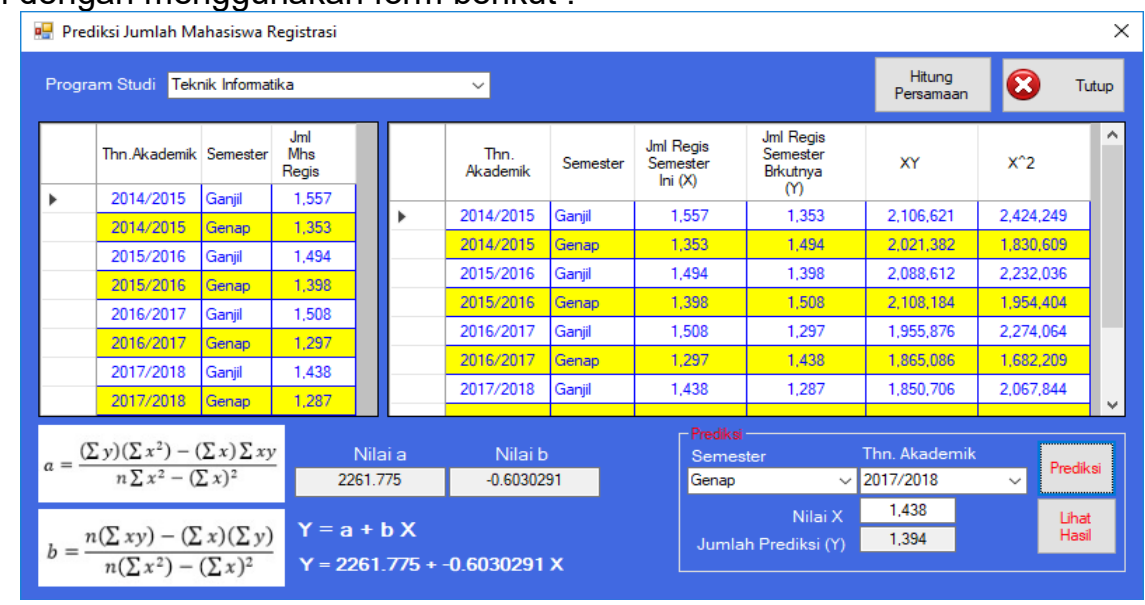

Gambar 3. Form Prediksi Jumlah Mahasiswa Registrasi

Form ini digunakan untuk melakukan proses perhitungan metode Linier Regresi dan melakukan prediksi jumlah mahasiswa registrasi berdasarkan program studi yang akan diprediksi.

Berdasarkan hasil penelitian di atas, berikut diuraikan cara penerapan metode Linier Regresi dalam memprediksi jumlah mahasiswa registrasi untuk semester berikutnya :

Tahap 1. Pembuatan/Pengolahan Dataset Penelitian

Berikut dataset mahasiswa registrasi untuk program studi Teknik Informatika dengan menggunakan Linier Regresi sederhana :

Tabel 1. Dataset Penelitian Prodi Teknik Informatika

\begin{tabular}{|c|c|c|}
\hline Tahun Akademik & Semester & $\begin{array}{c}\text { Jumlah Mahasiswa } \\
\text { Registrasi (Orang) }\end{array}$ \\
\hline $2014 / 2015$ & Ganjil & 1,557 \\
\hline $2014 / 2015$ & Genap & 1,353 \\
\hline $2015 / 2016$ & Ganjil & 1,494 \\
\hline $2015 / 2016$ & Genap & 1,398 \\
\hline $2016 / 2017$ & Ganjil & 1,508 \\
\hline $2016 / 2017$ & Genap & 1,297 \\
\hline $2017 / 2018$ & Ganjil & 1,438 \\
\hline $2017 / 2018$ & Genap & 1,287 \\
\hline
\end{tabular}

Tahap 2. Pembentukan model Linier Regresi yang terdiri dari :

a. Hitung $\mathrm{X}^{2}, \mathrm{XY}$ dan total dari masing-masing kolom

Tabel 2. Perhitungan $\mathrm{X}^{2}$ dan $\mathrm{XY}$ Prodi Teknik Informatika

\begin{tabular}{|l|l|r|r|r|r|}
\hline $\begin{array}{c}\text { Tahun } \\
\text { Akademik }\end{array}$ & Semester & $\begin{array}{c}\text { Jumlah } \\
\text { Mahasiswa } \\
\text { Registrasi } \\
\text { Semester } \\
\text { Ini (X) }\end{array}$ & $\begin{array}{c}\text { Jumlah } \\
\text { Mahasiswa } \\
\text { Registrasi } \\
\text { Semester } \\
\text { Berikutnya (Y) }\end{array}$ & XY & $\mathbf{X}^{\mathbf{2}}$ \\
\hline $2014 / 2015$ & Ganjil & 1,557 & 1,353 & $2,106,621$ & $2,424,249$ \\
\hline $2014 / 2015$ & Genap & 1,353 & 1,494 & $2,021,382$ & $1,830,609$ \\
\hline $2015 / 2016$ & Ganjil & 1,494 & 1,398 & $2,088,612$ & $2,232,036$ \\
\hline $2015 / 2016$ & Genap & 1,398 & 1,508 & $2,108,184$ & $1,954,404$ \\
\hline $2016 / 2017$ & Ganjil & 1,508 & 1,297 & $1,955,876$ & $2,274,064$ \\
\hline
\end{tabular}


ILKOM Jurnal IImiah Volume 10 Nomor 2 Agustus 2018

\begin{tabular}{|r|l|r|r|r|r|}
\hline $2016 / 2017$ & Genap & 1,297 & 1,438 & $1,865,086$ & $1,682,209$ \\
\hline $2017 / 2018$ & Ganjil & 1,438 & 1,287 & $1,850,706$ & $2,067,844$ \\
\hline \multicolumn{2}{|c|}{ Total } & $\mathbf{1 0 , 0 4 5}$ & $\mathbf{9 , 7 7 5}$ & $\mathbf{1 3 , 9 9 6 , 4 6 7}$ & $\mathbf{1 4 , 4 6 5 , 4 1 5}$ \\
\hline
\end{tabular}

b. Hitung nilai a dengan menggunakan persamaan (2) dan nilai b menggunakan persamaan (3).

$$
\begin{aligned}
& a=\frac{(9775)(14465415)-(10045)(13996467)}{7(14465415)-(10045)^{2}} \\
& a=\frac{141399431625-140594511015}{101257905-100902025}=\frac{804920610}{355880}=2261.775 \\
& b=\frac{7(13996467)-(10045)(9775)}{7(14465415)-(10045)^{2}} \\
& b=\frac{97975269-98189875}{101257905-100902025}=\frac{-214606}{355880}=-0.6030291
\end{aligned}
$$

c. Buatkan model persamaan Linier Regresi sederhana dengan menggunakan persamaan (1).

$$
Y=2261.775+(-0.6030291) x
$$

d. Lakukan prediksi atau peramalan terhadap variabel faktor penyebab atau variabel akibat. Misalnya akan mencari nilai Y (semester Ganjil 2018/2019) dengan x (semester Genap 2017/2018) = 1,287

$$
Y=2261.775+(-0.6030291)(1287)=1485
$$

Tahap 3. Pengujian performa berdasarkan model prediksi yang telah dibuat dengan input data testing dengan output MAPE dengan menggunakan persamaan (4).

Untuk melakukan pengujian performa model yang sudah dibuat, maka dilakukan prediksi dengan menggunakan dataset pada Prodi Teknik Informatika mulai dari Semester Genap Tahun Akademik 2014/2015 s/d Semester Genap 2017/2018, dimana data untuk variabel x adalah data pada semeseter sebelumnya dengan hasil perhitungan sebagai berikut :

Tabel 3. Perhitungan Tingkat Error MAPE Prodi Teknik Informatika

\begin{tabular}{|c|c|c|c|c|c|c|}
\hline $\begin{array}{c}\text { Tahun } \\
\text { Akademik }\end{array}$ & Semester & $\begin{array}{c}\text { Dataset } \\
\text { Semester } \\
\text { Sebelumnya } \\
(\mathbf{x})\end{array}$ & $\begin{array}{c}\text { Data } \\
\text { Aktual } \\
(\mathbf{y})\end{array}$ & $\begin{array}{c}\text { Data } \\
\text { Prediksi } \\
\left(\mathbf{y}^{\prime}\right)\end{array}$ & $\begin{array}{c}\text { Selisih } \\
(\mathbf{y} \text {-y') }\end{array}$ & $\begin{array}{c}\text { Error } \\
\text { MAPE } \\
(\mathbf{\%})\end{array}$ \\
\hline $2014 / 2015$ & Genap & 1,557 & 1,353 & 1,322 & 31 & 2.29 \\
\hline $2015 / 2016$ & Ganjil & 1,353 & 1,494 & 1,445 & 49 & 3.28 \\
\hline $2015 / 2016$ & Genap & 1,494 & 1,398 & 1,360 & 38 & 2.72 \\
\hline $2016 / 2017$ & Ganjil & 1,398 & 1,508 & 1,418 & 90 & 5.97 \\
\hline $2016 / 2017$ & Genap & 1,508 & 1,297 & 1,352 & -55 & 4.24 \\
\hline $2017 / 2018$ & Ganjil & 1,297 & 1,438 & 1,479 & -41 & 2.85 \\
\hline $2017 / 2018$ & Genap & 1,438 & 1,287 & 1,394 & -107 & 8.31 \\
\hline & & & & Total & $\mathbf{2 9 . 6 6}$ \\
\hline
\end{tabular}

$$
M A P E=\frac{29.66 \times 100 \%}{7}=4.24 \%
$$

Berdasarkan hasil pengujian tingkat error prediksi mahasiswa registrasi untuk prodi Teknik Informatika didapatkan hasil $4.24 \%$ atau tingkat akurasi sebesar $95.76 \%$.

Tahapan yang sama dilakukan untuk dataset prodi Ilmu Hukum dengan dataset sebagai berikut :

Tahap 1. Pembuatan/Pengolahan Dataset Penelitian

Tabel 4. Dataset Penelitian Prodi Ilmu Hukum

\begin{tabular}{|c|c|r|}
\hline Tahun Akademik & Semester & $\begin{array}{c}\text { Jumlah Mahasiswa } \\
\text { Registerasi (Orang) }\end{array}$ \\
\hline $2014 / 2015$ & Ganjil & 789 \\
\hline $2014 / 2015$ & Genap & 925 \\
\hline $2015 / 2016$ & Ganjil & 1,113 \\
\hline $2015 / 2016$ & Genap & 980 \\
\hline
\end{tabular}




\begin{tabular}{|c|c|r|}
\hline Tahun Akademik & Semester & $\begin{array}{c}\text { Jumlah Mahasiswa } \\
\text { Registerasi (Orang) }\end{array}$ \\
\hline $2016 / 2017$ & Ganjil & 1,203 \\
\hline $2016 / 2017$ & Genap & 1,026 \\
\hline $2017 / 2018$ & Ganjil & 1,165 \\
\hline $2017 / 2018$ & Genap & 1,067 \\
\hline
\end{tabular}

Tahap 2. Pembentukan model Linier Regresi yang terdiri dari :

a. Hitung $X^{2}, X Y$ dan total dari masing-masing kolom

Tabel 5. Perhitungan $\mathrm{X}^{2}$ dan $\mathrm{XY}$ Prodi IImu Hukum

\begin{tabular}{|r|l|r|r|r|r|}
\hline $\begin{array}{c}\text { Tahun } \\
\text { Akademik }\end{array}$ & Semester & $\begin{array}{c}\text { Jumlah } \\
\text { Mahasiswa } \\
\text { Registrasi } \\
\text { Semester } \\
\text { Ini (X) }\end{array}$ & $\begin{array}{r}\text { Jumlah } \\
\text { Mahasiswa } \\
\text { Registrasi } \\
\text { Semester } \\
\text { Berikutnya (Y) }\end{array}$ & \multicolumn{1}{|c|}{ XY } & \multicolumn{1}{|}{$\mathbf{X}^{\mathbf{2}}$} \\
\hline $2014 / 2015$ & Ganjil & 789 & 925 & 729,825 & 622,521 \\
\hline $2014 / 2015$ & Genap & 925 & 1,113 & $1,029,525$ & 855,625 \\
\hline $2015 / 2016$ & Ganjil & 1,113 & 980 & $1,090,740$ & $1,238,769$ \\
\hline $2015 / 2016$ & Genap & 980 & 1,203 & $1,178,940$ & 960,400 \\
\hline $2016 / 2017$ & Ganjil & 1,203 & 1,026 & $1,234,278$ & $1,447,209$ \\
\hline $2016 / 2017$ & Genap & 1,026 & 1,165 & $1,195,290$ & $1,052,676$ \\
\hline $2017 / 2018$ & Ganjil & 1,165 & 1,067 & $1,243,055$ & $1,357,225$ \\
\hline \multicolumn{2}{|r|}{ Total } & $\mathbf{7 , 2 0 1}$ & $\mathbf{7 , 4 7 9}$ & $\mathbf{7 , 7 0 1 , 6 5 3}$ & $\mathbf{7 , 5 3 4 , 4 2 5}$ \\
\hline
\end{tabular}

b. Hitung nilai a dengan menggunakan persamaan (2) dan nilai b menggunakan persamaan (3)

$$
\begin{aligned}
& a=\frac{(7479)(7534425)-(7201)(7701653)}{7(7534425)-(7201)^{2}} \\
& a=\frac{56349964575-55459603253}{52740975-51854401}=\frac{890361322}{886574}=1004.272 \\
& b=\frac{7(7701653)-(7201)(7479)}{7(7534425)-(7201)^{2}} \\
& b=\frac{53911571-53856279}{52740975-51854401}=\frac{55292}{886574}=0.0623659
\end{aligned}
$$

c. Buatkan model persamaan Linier Regresi sederhana dengan menggunakan persamaan (1).

$$
Y=1004.272+0.0602366 x
$$

d. Lakukan prediksi. Misalnya akan mencari nilai $Y$ (semester Ganjil 2018/2019) dengan x (semester Genap 2017/2018) $=1,067$

$$
Y=1004.272+(0.0623659)(1067)=1071
$$

Tahap 3. Pengujian performa berdasarkan model prediksi yang telah dibuat dengan input data testing dengan output MAPE dengan menggunakan persamaan (4).

Tabel 6. Perhitungan Tingkat Error MAPE Prodi IImu Hukum

\begin{tabular}{|c|c|r|r|r|r|r|}
\hline $\begin{array}{c}\text { Tahun } \\
\text { Akademik }\end{array}$ & Semester & $\begin{array}{c}\text { Dataset } \\
\text { Semester } \\
\text { Sebelumnya } \\
(\mathbf{x})\end{array}$ & $\begin{array}{c}\text { Data } \\
\text { Aktual } \\
(\mathbf{y})\end{array}$ & $\begin{array}{c}\text { Data } \\
\text { Prediksi } \\
\left(\mathbf{y}^{\prime}\right)\end{array}$ & $\begin{array}{c}\text { Selisih } \\
(\mathbf{y} \text {-y') }\end{array}$ & $\begin{array}{c}\text { Error } \\
\text { MAPE } \\
(\%)\end{array}$ \\
\hline $2014 / 2015$ & Genap & 789 & 925 & 1,053 & -128 & 13.84 \\
\hline $2015 / 2016$ & Ganjil & 925 & 1,113 & 1,061 & 52 & 4.67 \\
\hline $2015 / 2016$ & Genap & 1,113 & 980 & 1,073 & -93 & 9.49 \\
\hline $2016 / 2017$ & Ganjil & 980 & 1,203 & 1,065 & 138 & 11.47 \\
\hline $2016 / 2017$ & Genap & 1,203 & 1,026 & 1,079 & -53 & 5.17 \\
\hline $2017 / 2018$ & Ganjil & 1,026 & 1,165 & 1,068 & 97 & 8.33 \\
\hline $2017 / 2018$ & Genap & 1,165 & 1,067 & 1,076 & -9 & 0.84 \\
\hline
\end{tabular}




\begin{tabular}{|c|c|c|c|c|c|c|}
\hline $\begin{array}{c}\text { Tahun } \\
\text { Akademik }\end{array}$ & Semester & $\begin{array}{c}\text { Dataset } \\
\text { Semester } \\
\text { Sebelumnya } \\
(\mathbf{x})\end{array}$ & $\begin{array}{c}\text { Data } \\
\text { Aktual } \\
(\mathbf{y})\end{array}$ & $\begin{array}{c}\text { Data } \\
\text { Prediksi } \\
\left(\mathbf{y}^{\prime}\right)\end{array}$ & $\begin{array}{c}\text { Selisih } \\
\left(\mathbf{y}-\mathbf{y}^{\prime}\right)\end{array}$ & $\begin{array}{c}\text { Error } \\
\text { MAPE } \\
(\%)\end{array}$ \\
\hline \multicolumn{7}{|c|}{ Total }
\end{tabular}

$$
M A P E=\frac{53.81 \times 100 \%}{7}=7.69 \%
$$

Berdasarkan hasil pengujian tingkat error prediksi mahasiswa registrasi untuk prodi IImu Hukum didaptkan hasil sebesar $7.69 \%$ atau tingkat akurasi sebesar $92.31 \%$.

\section{Kesimpulan dan Saran}

Berdasarkan hasil penelitian di atas dapat ditarik kesimpulan sebagai berikut :

1. Hasil prediksi dari 2 prodi yang dipilih yakni prodi Teknik Informatika dengan hasil pengujian tingkat error sebesar $4.24 \%$ atau tingkat akurasi sebesar $95.76 \%$ dan untuk prodi IImu Hukum dengan hasil pengujian tingkat error sebesar $7.69 \%$ atau tingkat akurasi sebesar $92.31 \%$.

2. Metode Linier Regresi dapat digunakan untuk memprediksi mahasiswa registrasi secara tepat dan aplikasi yang sudah dibangun dapat digunakan karena memiliki tingkat akurasi di atas $90 \%$.

3. Disarankan kepada peneliti berikutnya bahwa penelitian ini dapat diteliti kembali dengan menggunakan metode prediksi yang lain dan jumlah dataset yang lebih banyak lagi, agar hasilnya bisa dibandingkan mana yang lebih baik.

\section{Daftar Pustaka}

[1]. Tim Penyusun, "Panduan Akademik Unisan”, Gorontalo, Unisan, 2015.

[2]. Kristiono, D., "Peramalan (Forecasting) Potensi Pendapatan Asli Daerah Sebagai Sumber Pendapatan Daerah Kota Klaten Berbasis Android”, AMIKOM, Yogyakarta, 2014.

[3]. Pratama, Y.M., "Perancangan Aplikasi Prediksi Pengunjung Café Cost Coffee Menggunakan Metode Regresi Linear", journal.stth-medan.ac.id, 2016.

[4]. Muhammad, R., \& Hibertus, H., "Implementasi Algoritma Linear Regresi Untuk Prediksi Jumlah Wisatawan Mancanegara Melalui Bandara International Indonesia”, Jurnal IJCCS-Universitas Dian Nuswantoro, Semarang, 2017.

[5]. Eko, P., "Data Mining Konsep Dan Aplikasi Menggunakan Matlab", Yogyakarta, Andi Offset, 2012.

[6]. Eko, P., "Data Mining Mengolah Data Menjadi Informasi Menggunakan Matlab”, Yogyakarta, Andi Offset, 2014.

[7]. Maimon, O., \& Rokach, L., "Data Mining and Knowledge Discovery Handbook", New York, Springer, 2005.

[8]. Heizer, J.\& Render, B., "Manajemen Operasi”, Buku 1 Edisi 9. Jakarta, Salemba Empat, 2009.

[9]. Santosa, B., "Data Mining Teknik Pemanfaatan Data untuk Keperluan Bisnis", Yogyakarta, Graha IImu, 2007.

[10]. Hendy, T., dan Fan, A., "Analisa Perbandingan Metode Regresi Linear Dan Exponential Smoothing Dalam Parameter Tingkat Error", Jurnal Teknik Dan IImu Komputer. Vol. 02. No. 07, Universitas Bina Nusantara, 2013. 